\title{
Faktor Yang Berhubungan Dengan Keluhan Muskuloskeletal Pada Pekerja di PT. X Tahun 2019
}

\author{
Factors Related to Musculoskeletal Complaints in Workers at PT. X of \\ 2019 \\ Rizka Widitia ${ }^{1}$, Entianopa ${ }^{2}$, Abul Ainin Hapis $^{3}$ \\ ${ }^{123}$ Sekolah Tinggi Ilmu Kesehatan Harapan Ibu Jambi. Program Studi Kesehatan Masyarakat ${ }^{123}$ \\ Email corespondensi : rizkawiditia7@gmail.com
}

\begin{tabular}{|c|c|}
\hline $\begin{array}{l}\text { Track Record } \\
\text { Article } \\
\text { Diterima :220 Oktober } 2020 \\
\text { Dipublikasi: } 11 \text { Desember } \\
2020\end{array}$ & 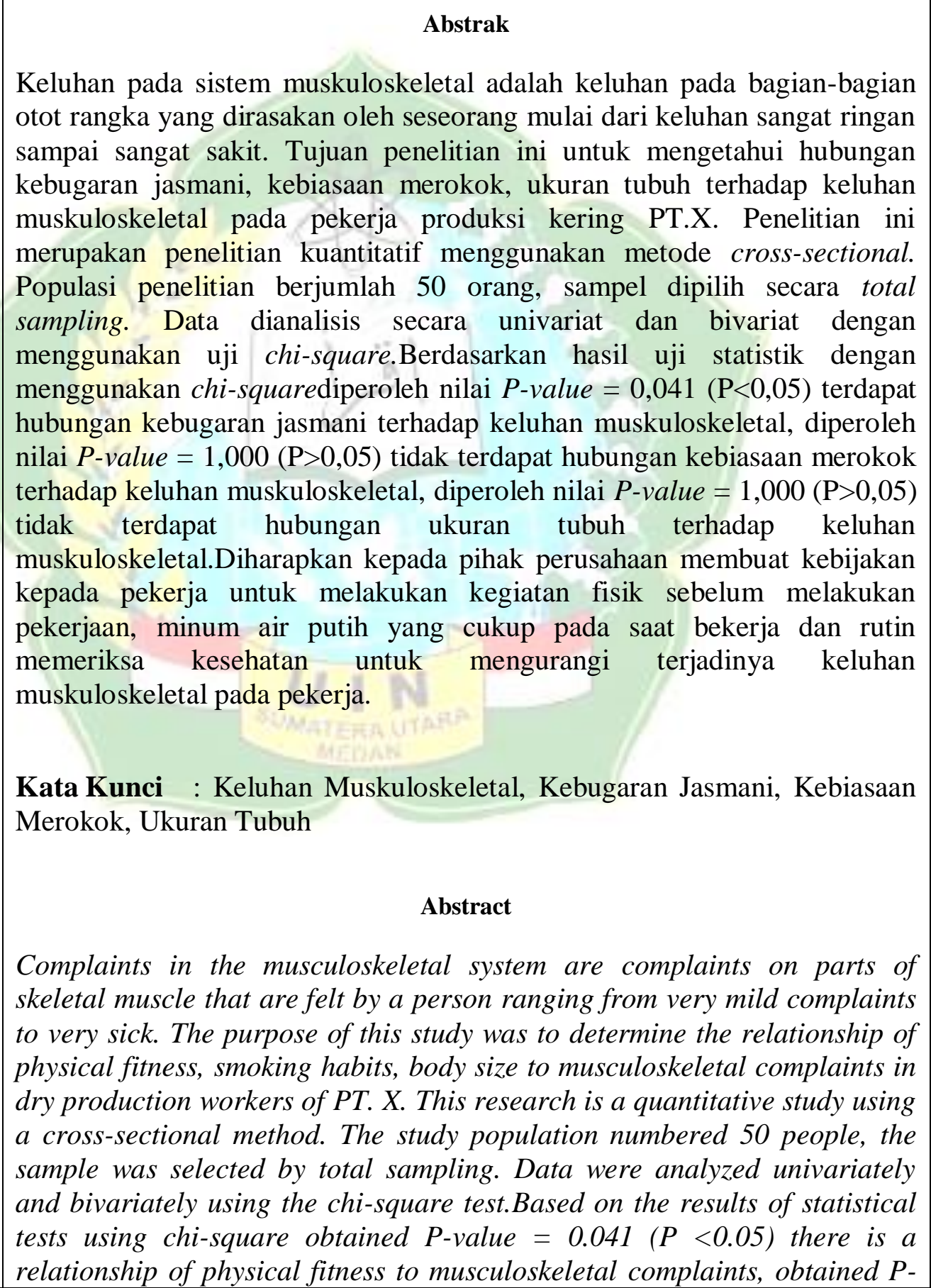 \\
\hline
\end{tabular}


Rizka Widitia, Entianopa, Abul Ainin Hapis/ Scientific Periodical of Public Health and Coastal2(2),2020, halaman 76-85

\begin{tabular}{|l|l|}
\hline value $=1,000(P>0.05)$ there is no relationship between smoking habits \\
with respect to musculoskeletal complaints, a P-value = 1,000 (P> 0.05) \\
was obtained with no body size relationship with musculoskeletal \\
complaints.It is expected that the company makes policies for workers to \\
carry out physical activities before doing work, drink enough water at work \\
and regularly check health to reduce the occurrence of musculoskeletal \\
complaints to workers. \\
Key words: Musculoskeletal Complaints, Physical Fitness, Smoking Habits, \\
Body Size
\end{tabular}

\section{Pendahuluan}

Ergonomi merupakan suatu ilmu, seni,- dan teknologi yang berupaya untuk menyerasikan alat, cara, dan lingkungan kerja terhadap kemampuan, kebolehan, dan segala keterbatasan manusia sehingga manusia dapat berkarya secara optimal tanpa pengaruh buruk dari pekerjaanya (Tarwaka, 2015). Gangguan kesehatan yang dialamin pekerja 40,5\% dari pekerjaan nya yaitu sebanyak 9482 pekerja di 12 kabupaten/kota di Indonesia, 16\% diantara nya menderita gangguan muskuloskeletal, $8 \%$ penyakit kardiovaskuler, $6 \%$ gangguan syaraf $3 \%$ gangguan pernafasan dan gangguan THT sebesar 1,5\%. Gangguan muskuloskeletal menyebabkan kerugian pada pekerja seperti jumlah hari yang hilang akibat sakit dan besar nya biaya kompensasi yang harus dikeluarkan(Kementerian Kesehatan RI, 2018) .

Musculoskeletal Disorders(MSDs) merupakan penyakit akibat kerja yang paling umum terjadi, demikianjuga Korea kasusnya mengalami peningkatan sebesar 3.868 dalam kurun tahun2010 hingga 2011(Pramana, 2015). Postur tubuh yang tidakergonomis selama bekerja dan beban fisik yang berlebihanadalah faktor yang paling signifikan mempengaruhi WorkRelated Musculoskeletal Disorders (WRMSDs)(Kim, 2015). Hasil penelitian menunjukkanbahwa prevalensi keluhan MSDscukup tinggi dirasakan oleh 26 pekerja (65\%)(Cindiyastira, 2014).Keluhan muskuloskeletal atau musculoskeletal disorders(MSDS) adalah keluhan sakit, nyeri, pegal-pegal danlainnya pada sistem otot (muskuloskeletal) seperti tendon,pembuluh darah, sendi, tulang, yang disebabkan olehaktivitas kerja. Ada 4 faktor yang dapat meningkatkantimbulnya MSDS yaitu postur yang tidak alamiah,tenaga yang berlebihan, pengulangan berkali-kali, danlamanya waktu kerja. Level MSDS dari yang paling ringanhingga yang berat akan mengganggu konsentrasi dalambekerja, menimbulkan kelelahan dan pada akhirnya akanmenurunkan produktivitas(Tarwaka, 2015).

Postur kerja yang tidak baik akan berdampak terhadap terjadinya keluhan muskuloskeletal pada pengoncek kelapa (Siregar, 2020). Semakin besar getaran maka 
Rizka Widitia, Entianopa, Abul Ainin Hapis/ Scientific Periodical of Public Health and Coastal2(2),2020, halaman 76-86

keluhan muskuloskeletal juga semakin meningkat(J et al., 2016). Postur kerja dan masa kerja berkaitan dengan keluhan muskuloskeletal(Safitri, 2017). Penelitian ini juga sejalan dengan penelitianRende (2015) mengenai hubungan antara posisi kerja duduk dengan keluhan muskuloskeletal dengan hasil statistik $\mathrm{p}=0,005(\mathrm{p}<0,05)$. Begitu juga dengan penelitian yang dilakukan olehWongkar (2017)mengenai hubungan antara postur kerja (posisi kerja) dengan keluhan musculoskeletal dengan hasil $\mathrm{p}=0,005(\mathrm{p}<0,05)$.

Berdasarkan data profil Dinas Kesehatan Kota Jambi, 10 penyakit terbesar di Kota Jambi salah satunya adalah penyakit otot dan jaringan ikat yang berjumlah 13.374 kasus pada tahun 2017 dan jika dipersenkan menjadi 4,28\% dan pada tahun 2018 menjadi 12.248 kasus atau 4,56\% (Dinas Kesehatan Provinsi Jambi, 2018).Berdasarkan data yang diperoleh dari PT. X jumlah seleruh pekerja yaitu sebanyak 245 orang. Dimana untuk bagian produksi merupakan bagian yang memiliki jumlah pekerja paling banyak diantara bagian yang lain dengan jumlah pekerja sebanyak 54 orang. Dari data yang di dapati tersebut, hanya bagian produksi kering yang menggunakan sumber daya manusia paling banyak sehingga penulis memilih bagian produksi kering sebagai populasi penelitian.

Konsumsi makanan yang tidak sehat akan membuat terjadinya peningkatan berat badan dan mempengaruhi kesehatan masyarakat (Adinda, 2020). Konsumsi makanan yang baik juga akan dapat meningkatkan stamina dan ketahanan tubuh (Fatimah, 2020). Kaitan IMT dengan risiko WMSDs adalah semakin gemuk seseorang maka bertambah besar risikonya untuk mengalami WMSDs. Hal ini disebabkan karena seseorang yang memiliki IMT tinggi akan berusaha menyangga berat badan dari depan dengan mengontraksikan otot punggung bawah. Dan bila ini berlanjut terus menerus, akan meyebabkan penekanan pada bantalan saraf tulang belakang yang dapat mengakibatkan hernia nucleus pulposus.

\section{Metode}

Penelitian ini adalah penelitian kuntitatif dengan pendekatan cross sectional yang bertujuan untuk mengetahui hubungan kebugaran jasmani, kebiasaan merokok dan ukuran tubuh dengan keluhan musculoskeletal pada pekerja produksi kering di PT. X. Penelitian ini dilakukan dengan menggunakan kuesioner Nordic Body Map, pengukuran denyut nadi dan pengukuran ukuran tubuh. observasi Populasi penelitian ini adalah seluruh industripengrajin kue yang ada di wilayah kerja Puskesmas Putri Ayu Kota Jambi. Teknik pengambilan sampel menggunakan teknik total sampling dengan jumlah sampel sebanyak 30 responden. Data dianalisis secara univariat dan bivariat kemudian dianalisis menggunakan Uji Chi-Square. 


\section{Hasil}

Berdasarkan penelitian yang telah dilakukan di peroleh hasil bahwa dari 50 responden terdapat , 8 responden $(16,0 \%)$ memiliki keluhan muskuloskeletal, 31 responden $(62,0 \%)$ memiliki kebugaran jasmani yang berat, 36 responden $(72,0 \%)$ memiliki kebiasaan merokok sedang, 11 responden $(28,0 \%)$ memiliki ukuran tubuh gemuk.

Tabel .1

Distribusi Keluhan Muskuloskeletal, Kebugaran Jasmani, Kebiasaan Merokok Dan Ukuran Tubuh

\begin{tabular}{cccc}
\hline No & Variabel & Frekuensi & Persentasi \\
\hline $\mathbf{1}$ & Keluhan muskuloskeletal & & \\
& Tinggi & 42 & 84,0 \\
& Rendah & 8 & 16,0 \\
\hline $\mathbf{2}$ & Kebugaran Jasmani & 31 & 62,0 \\
& Berat & 19 & 38,0 \\
\hline $\mathbf{3}$ & Ringan & & \\
& Kebiasaan Merokok & 36 & 72,0 \\
& Perokok sedang & 14 & 28,0 \\
\hline $\mathbf{4}$ & Tidak Merokok & & 28,0 \\
& Ukuran Tubuh & 14 & 63,3 \\
\hline
\end{tabular}

Hasil analisis bivariat menunjukkan bahwa :

a. Terdapat hubungan yang bermakna antara kebugarn jasmani pada pekerja produksi kering di PT. X

b. Tidak Terdapat hubungan yang bermakna antara kebiasaan merokok pada pekerja produksi kering di PT. X

c. Tidak Terdapat hubungan yang bermakna antara ukuran tubuh pada pekerja produksi kering di PT. X

Tabel . 2

Hubungan Kebugaran Jasmani, Kebiasaan Merokok dan Ukuran Tubuh Pada Pekerja Produksi Kering di PT. X

\begin{tabular}{|c|c|c|c|c|c|c|c|}
\hline \multirow{3}{*}{$\begin{array}{c}\text { Variabel } \\
\text { independen }\end{array}$} & \multicolumn{4}{|c|}{ Keluhan Muskuloskeletal } & \multirow{2}{*}{\multicolumn{2}{|c|}{ Total }} & \multirow[t]{3}{*}{ p-value } \\
\hline & \multicolumn{2}{|c|}{ Tinggi } & \multicolumn{2}{|c|}{ Rendah } & & & \\
\hline & $\mathbf{n}$ & $\%$ & $\mathbf{n}$ & $\%$ & $\mathbf{n}$ & $\%$ & \\
\hline $\begin{array}{c}\text { Kebugaran } \\
\text { Jasmani }\end{array}$ & & & & & & & 0,041 \\
\hline Berat & 29 & 93,5 & 2 & 6,5 & 31 & 100 & \\
\hline Ringan & 13 & 68,4 & 6 & 31,6 & 19 & 100 & \\
\hline
\end{tabular}


Rizka Widitia, Entianopa, Abul Ainin Hapis/ Scientific Periodical of Public Health and Coastal2(2),2020, halaman 76-86

\begin{tabular}{|c|c|c|c|c|c|c|c|}
\hline $\begin{array}{c}\text { Kebiasaan } \\
\text { Merokok }\end{array}$ & & & & & & & \multirow[t]{3}{*}{1,000} \\
\hline Perokok Sedang & 30 & 83,3 & 6 & 16,7 & 36 & 100 & \\
\hline Tidak Perokok & 12 & 85,7 & 2 & 14,3 & 14 & 100 & \\
\hline \multicolumn{8}{|l|}{ Ukuran Tubuh } \\
\hline Gemuk & 12 & 85,7 & 2 & 14,3 & 14 & 100 & \\
\hline Normal & 30 & 83,3 & 6 & 16,7 & 36 & 100 & 1,000 \\
\hline
\end{tabular}

\section{Pembahasan}

\section{Hubungan Kebugaran Jasmani Dengan Keluhan Muskuloskeletal Pada Pekerja Produksi Kering di PT. X}

Berdasarkan hasil uji statistik menggunakan chi-square pengaruh kebugaran jasmani terhadap keluhan muskuloskeletal di peroleh nilai $P$-value $=0,041(P$-value $<0,05)$, secara statistik terdapat hubungan antara variabel kebugaran jasmani terhadap keluhan muskuloskeletal padapekerjaproduksikering di PT. X.

Keluhan otot lebih jarang ditemukan pada seseorang yang dalam aktivitas kesehariannya mempunyai cukup waktu untuk istirahat. Sebaliknya, bagi yang dalam kesehariannya melakukan pekerjaan yang memerlukan pengerahan tenaga yang besar, di sisi lain tidak mempunyai waktu yang cukup untuk istirahat, hamper dapat dipastikan akan terjadi keluhan otot(Tarwaka, 2015).

MenurutHasrianti (2016) tingkat kesegaran jasmani yang rendah akanmeningkatkan risiko terjadinya keluhan otot. Kesegaran tubuh terdiri dari 10 komponen yaitu: kekuatan, daya tahan, kecepatan, kelincahan, kelenturan,keseimbangan, kekuatan, koordinasi, ketepatan, dan waktu reaksi

Menurut penelitianAsri, (2019) dari hasil uji statistik didapatkan nilai p-value sebesar 0,611 artinya tidak ada hubungan antara kesegaran jasmani terhadap keluhan muskuloskeletal pada pengrajin manik kaca.Berdasarkan hasil penelitian yang telah dilakukan menunjukkan bahwa responden yang memiliki kategori kesegaran jasmani kurang mengalami tingkat keluhan muskoskeletal sedang, sedangkan responden yang memiliki kesegaran jasmani sedang mengalami tingkat keluhan musculoskeletal rendah.Salah satu faktor yang mempengaruhi kesegaran jasmani adalah tidur dan istirahat. Orang yang memiliki tidur dan istirahat yang kurang akan berpengaruh pada kesegaran jasmaninya. Keluhan otot akan terjadi pada seseorang melakukan aktivitas dengan pengerahan tenaga yang besar tanpa memiliki waktu istirahat yang cukup. Sehingga dapat dipastikan bahwa orang yang memiliki kesegaran jasmani yang kurang akan mudah mengalami keluhan otot. ${ }^{6}$ Tingkat kesegaran 
Rizka Widitia, Entianopa, Abul Ainin Hapis/ Scientific Periodical of Public Health and Coastal2(2),2020, halaman 76-86

jasmani yang rendah akan meningkatkan risiko terjadinya keluhan otot. Apabila olahraga dilakukan scara teratur maka akan mengurangi risiko terjadinya keluhan otot dan membuat tubuh lebih bugar dan fit(Helmina, 2019).

Penelitian yang dilakukan di PT. X menunjukkan bahwa kurangnya kebiasaan melakukan peregangan sebelum memulai pekerjaan menyebabkan pekerja mengalami keluhan kelelahan ditambah dengan aktivitas yang berulang, posisi kerja berdiri lama dan diruangan yang panas. Pekerja tidak sarapan pagi sebelum melakukan pekerjaan, tidak mengkonsumsi air minum sebanyak 2 liter perhari, dan pekerja tidak berolah raga secara rutin, sehingga hal inilah yang dapat menyebabkan kurangnya kebugaran pada pekerja.

Hasil penelitian ini diperkuat oleh penelitian Cindiyastira (2014) yang menunjukkan bahwa terdapat hubungan yang bermakna antara kebiasaanberolahraga dengan keluhan Musculoskeletal Disorders (MSDs). Hasil ini juga dapatdipengaruhi oleh tingkat kebiasaan olahraga seseorang, pada umumnya mempunyaicukup waktu untuk untuk berolahraga dan sebaliknya, bagi orang bekerja dalamkesehariannya memerlukan banyak tenaga dan tidak cukup beristirahat akan lebihsering mengalami keluhan otot. Tingkat kesegaran tubuh yang rendah akanmempertinggi risiko kejadian terjadinya keluhan otot, sikap kerja yang dilakukanbergantung dari kondisi sistem kerja yang ada. Sikap kerja menjadi faktor yang paling dominan terhadap kejadian keluhan Musculoskeletal Disorders (MSDs)(Mallapiang, 2016).

Upaya yang dapat dilakukan adalah dengan melakukan peregangan sebelum memulai pekerjaan, sarapan pagi sebelum bekerja, mengkonsumsi air minum 2 liter perhari, dan melakukan oleh raga rutin ditambah dengan pihak perusahaan membuat kebijakan untuk pekerja agar melakukan peregangan sebelum memulai pekerjaan hal ini penting untuk kesehatan dan kenyamanan pekerja saat melakukan aktivitas.

\section{Hubungan Kebiasaan Merokok terhadap Keluhan Muskuloskeletal pada}

\section{Pekerja Produksi Kering di PT. X}

Berdasarkan hasil uji statistik menggunakan chi-square pengaruh kebiasaan merokok terhadap keluhan muskuloskeletal di peroleh nilai $\mathrm{P}$-value $=1,000(\mathrm{P}$-value $>0,05)$, secara statistiktidak terdapat hubungan antara variabel kebiasaan merokok terhadap keluhan muskuloskeletal pada pekerja produksi kering di PT. X

Pengaruh kebiasaan merokok terhadap risiko keluhan otot juga masih diperdebatkan oleh para ahli, namun demikian, beberapa penelitian telah membuktikan bahwa meningkatnya keluhan otot sangat erat hubungannya dengan lama dan tingkat kebiasaan 
Rizka Widitia, Entianopa, Abul Ainin Hapis/ Scientific Periodical of Public Health and Coastal2(2),2020, halaman 76-86

merokok. Semakin lama dan semakin tinggi frekuensi merokok, semakin tinggi pula tingkat keluhan otot yang dirasakan(Tarwaka, 2015).

Penelitian oleh para ahli diperoleh bahwa meningkatnya frekuensi merokok akan meningkatkan keluhan otot hingga $20 \%$ untuk setiap 10 batang rokok per hari. Kebiasaan merokok akan menurunkan kapasitas paru-paru sehingga kemampuan untuk mengonsumsi oksigen akan menurun, sehingga apabila pekerja tersebut dituntut untuk pekerjaan dengan pengerahan tenaga maka akan mudah merasakan lelah karena kandungan oksigen dalam darah rendah.Dari hasil uji statistik Chi- Square diperoleh nilai $(\mathrm{p}=0,006)$ yang berarti ada hubungan yang bermakna kebiasaan merokok dengan keluhan Musculoskeletal Disorders (MSDs) (Rahman, 2017).

Hasil penelitian yang dilakukan pada pekerja di PT. X didapatkan hasil bahwa tidak terdapat hubungan antara kebiasaan merokok dengan keluhan musculoskeletal dikarenakan pada saat pekerja produksi di PT. X sedang melakukan pekerjaan, mereka menyatakan merokok tidak mempengaruhi keluhan pada otot melainkan yang mempengaruhi keluhan pada otot yaitu berupa beban kerja yang mereka lakukan berlebihan. Hasil penelitian Krisdanto (2016) bahwa tidakterdapat hubungan yang bermakna antara kebiasaan merokok dengan keluhanMusculoskeletal Disorders (MSDs).

Efek yang ditimbulkan dari bahaya rokok bersifat kronik sehinggaada kemungkinan bahwa pada saat penelitian dilakukan belum terlihat pengaruh/efekdari bahaya rokok yang berarti pada pekerja. Selain itu, kemungkinan pekerja yangtidak merokok banyak yang melakukan pekerjaan dengan risiko pekerjaan tinggisehingga mengalami keluhan Musculoskeletal Disorders (MSDs). Oleh karena itu,meskipun kebiasaan merokok berperan untuk menyebabkan keluhan MusculoskeletalDisorders (MSDs) namun pengaruh dari rokok juga didukung oleh faktor lain sepertirisiko pekerjaan, usia, masa kerja, kebiasaan olahraga, dan lain-lain.

\section{Hubungan Ukuran Tubuh Dengan Keluhan Muskuloskeletal Pada Pekerja Produksi Kerinf di PT. X}

Indeks masa tubuh karyawan lebih banyak pada kategori normal dimana karyawan memiliki berat badan dan tinggi badan yang normal sehingga keluhan muskuloskeletal yang dirasakan para karyawan cenderung pada kategori keluhan rendah dan keseimbangan otot rangka dalam menerima beban masih pada batas normal. Kaitan IMT dengan keluhan muskuloskeletal yaitu semakin gemuk seseorang maka semakin bertambah besar risiko untuk mengalami keluhan muskuloskeletal (Bobaya, 2018). 
Rizka Widitia, Entianopa, Abul Ainin Hapis/ Scientific Periodical of Public Health and Coastal2(2),2020, halaman 76-86

Berdasarkan hasil uji statistik menggunakan chi-square pengaruh ukuran tubuh terhadap keluhan muskuloskeletal di peroleh nilai P-value $=1,000$ (P-value $>0,05)$, secara statistik tidak terdapat hubungan antara variabel ukuran terhadap keluhan muskuloskeletal pada pekerja produksi kering di PT. X

Berat badan, tinggi badan dan masa tubuh juga merupakan faktor yang dapat menyebabkan terjadinya keluhan sistem muskuloskeletal. Temuan lain menyatakan bahwa tubuh yang tinggi umumnya sering menderita keluhan sakit punggung, tetapi tubuh tinggi tidak mempunyai pengaruh terhadap keluhan pada leher, bahu dan pergelangan tangan(Tarwaka, 2015).

Menurut penelitian Anastasya, (2019) berdasarkan dari hasil uji spearman antara indeks masa tubuh dengan keluhan muskuloskeletal dengan hasil nilai $\mathrm{p}=0,793$ yang berarti $\mathrm{H} 0$ diterima dengan kata lain, tidak terdapat hubungan antara indeks masa tubuh dengan keluhan muskuloskeletal pada karyawan di Bank Sulut Go Cabang Utama Manado. Indeks masa tubuh karyawan lebih banyak pada kategori normal dimana karyawan memiliki berat badan dan tinggi badan yang normal sehingga keluhan muskuloskeletal yang dirasakan para karyawan cenderung pada kategori keluhan rendah dan keseimbangan otot rangka dalam menerima beban masih pada batas normal. Hal ini sejalan dengan teori dari Tarwaka (2015)bahwa keluhan sistem muskuloskeletal yang terkait dengan ukuran tubuh lebih disebabkan oleh kondisi keseimbangan struktur rangka dalam menerima beban, baik beban berat tubuh maupun beban tambahan lainnya.

Pada individu yang overweight ataupun obesitas ditemukan terdapat kerusakan pada sistem muskuloskeletal yang yang bermanifestasi sebagai nyeri dan discomfort.Keluhan MSDs yang umum terjadi pada individu yang obesitas seperti nyeri leher, tendinitis rotator cuff, osteoatritis pada lutut, nyeri kaki, dan cedera tendon Achilles. Keluhan muskuloskeletal yang terjadi disebabkan oleh pengaruh ukuranantropometri terkait pada keseimbangan dari struktur rangka dalam menerima beban baik berat tubuh maupun beban dari pekerjaan(Tjahayuningtyas, 2019).

Terdapat hubunganantara durasi kerja dan IMT yangdipengaruhi oleh durasi kerjayang tinggi dan IMT yang cukuptinggi. Disarankan penjahitdengan durasi kerja >8 jam harusmerubah waktu kerjanya guna menghindari terjadinya keluhanMusculoskeletal Disorders(MSDs) menjadi lebih tinggi yang dapat menggangu kesehatan serta proses pekerjaan serta pekerja dengan nilai IMT yang tinggi melakukan relaksasi pada tubuh sekitar 15-20 menit untuk mengurangi rasa nyeri pada tubuh(Icsal, 2016). 
Hasil penelitian yang dilakukan di PT. X didapatkan hasil bahwa tidak terdapat hubungan antara ukuran tubuh dengan keluhan muskuloskeletal dikarenakan ukuran tubuh pekerja lebih banyak pada kategori normal, Indeks masa tubuh karyawan lebih banyak pada kategori normal dimana karyawan memiliki berat badan dan tinggi badan yang normal sehingga keluhan muskuloskeletal yang dirasakan para karyawan cenderung pada kategori keluhan rendah dan keseimbangan otot rangka dalam menerima beban masih pada batas normal. Hal ini sejalan dengan teori dariTarwaka (2015)bahwa keluhan sistem muskuloskeletal yang terkait dengan ukuran tubuh lebih disebabkan oleh kondisi keseimbangan struktur rangka dalam menerima beban, baik beban berat tubuh maupun beban tambahan lainnya.

Kaitan IMT dengan risiko WMSDs adalahsemakin gemuk seseorang maka bertambah besarrisikonya untuk mengalami WMSDs. Hal inidisebabkan karena seseorang yang memiliki IMTtinggi akan berusaha menyangga berat badan daridepan dengan mengontraksikan otot punggungbawah. Dan bila ini berlanjut terus menerus, akanmeyebabkan penekanan pada bantalan saraf tulangbelakang yang dapat mengakibatkan hernia nucleuspulposus

\section{Kesimpulan dan Saran}

Terdapat hubungan antara kebugaran jasmani dengan keluhan muskuloskeletal pada pekerja produksi kering di PT. X. Tidak terdapat hubungan antara kebiasaan merokok dengan keluhan muskuloskeletal pada pekerja produksi kering di PT. X. Tidak terdapat hubungan antara ukuran tubuh dengan keluhan muskuloskeletal pada pekerja produksi kering di PT. X

Berdasarkan penelitian tentang hubungan kebugaran jasmani, kebiasaan merokok dan ukuran tubuh dengan keluhan muskuloskeletal pada pekerja produksi kering di PT. X, saran yang diajukan peneliti adalah Sebaiknya perusahaan membuat kebijakan kepada karyawan untuk melakukan kegiatan fisik sebelum memulai pekerjaan.Para pekerja dapat membiasakan diri untuk memeriksa kesehatan secara rutin dan melakukan aktivitas fisik sebelum memulai pekerjaan.Sebagai bahan acuan untuk melakukan penelitian berikutnya dengan menambahkan variabel-variabel lain yang dapat menurunkan keluhan muskuloskeletal pada sasaran yang berbeda. 


\section{DaftarPustaka}

Adinda, D. (2020). Kebiasaan Makan, Body Image dan Status Gizi Remaja Putri. Jurnal Contagion, 2(1), 39-50.

Anastasya Jessica Gloria, S. (2019). Hubungan Antara Posisi Kerja Duduk Dan Indeks Masa Tubuh Dengan Keluhan Musuloskeletal Pada Karyawan Di Bank Sulutgo Cabang Utama. Kesmas: National Public Health Journal, 8(7), 380-387.

Asri, C. (2019). Hubungan Kesegaran Jasmani Dan Sikap Kerja Dengan Keluhan Muskuloskeletal Pada PengrajinManik Kaca Di Jombang. Jurnal Keperawatan Muhammadiyah, 2(1), 106-109. https://doi.org/10.30651/jkm.v4i2.2085

Bobaya, W., Kandou. (2018). Hubungan Antara Status Gizi, Umur Dan Beban Kerja Fisik Dengan Keluhan Muskuloskeletal Pada Tenaga Kerja Bongkar Muat Di Pelabuhan Manado. Community Health, 3(1), 1-10.

Cindiyastira, D. (2014). Hubungan Intensitas Getaran Dengan Keluhan Muskuloskeletal Diorders (Msds) Pada Tenaga Kerja Unit Produksi Paving Block Cv.Sumber Galian Makassar. Universitas Hasanuddin.

Dinas Kesehatan Provinsi Jambi. (2018). Laporan Dinas Kesehatan Provinsi Jambi.

Fatimah, P. S. (2020). Konsumsi Buah, Sayur Dan Ikan Berdasarkan Sosio Demografi Masyarakat Pesisir Provinsi Sumatera Utara. Uin Sumatera Utara. Contagion : Scientific Periodical of Public Health and Coastal Health, 2(1), 51-63.

Hasrianti, Y. (2016). Hubungan Postur Kerja dengan Keluhan Muskuloskeletal Pada Pekerja Di PT. Maruki Internasional Makassar. Universitas Hasanuddin.

Helmina, D. (2019). Hubungan Umur, Jenis Kelamin , Masa Kerja Dan Kebiasaan Olahraga Dengan Keluhan Musculoskeletal Disorders (MSDs) Pada Perawat. Caring Nursing Journal, 3(1), 2330.

Icsal, M. (2016). Faktor Yang Berhubungan Dengan Keluhan Muskuloskeletal Disorders (MSDs) Pada Penjahit Wilayah Pasar Panjang Kota Kendari Tahun 2016. Universitas Halu Oleo.

Kementerian Kesehatan RI. (2018). Hasil Utama Riskesdas 2018. http://www.kemkes.go.id/resources/download/info-terkini/hasil-riskesdas-2018.pdf

Kim. (2015). Risk Factors of Work Related Upper Extermity Musculoskeletal Disorder in Male Cameramen. Jurnal. Korea: Annalas of Occupational and Environmental Medicine, 1(1), 1-10.

Krisdanto. (2016). Hubungan Faktor Iindividu Dan Faktor Pekerjaan Dengan Keluhan Muskuloskeletal Akibat Kerja (Studi Pada Nelayan Di Desa Puger Wetan Kecamatan Puger Kabupaten Jember). Universitas Jember.

Mallapiang, F. (2016). Penilaian Risiko Ergonomi Postur Kerja Dengan Metode Quick Exposure Checklist ( QEC) Pada Perajin Mebel UD. Pondok Mekar Kelurahan Antang Kecamatan Manggala Kota Makassar. UIN Alauddin. 
Rizka Widitia, Entianopa, Abul Ainin Hapis/ Scientific Periodical of Public Health and Coastal2(2),2020, halaman 76-86

Pramana, I. G. P. I. Y. (2015). Hubungan Sikap Kerja Dengan KeluhanMuskuloskeletal Pada Pengrajin Patung Kayu Di Desa Kemenuh, Gianyar Tahun 2015. Universitas Udayana.

Rahman, A. (2017). Analisis Postur Kerja dan Faktor yang Berhubungan dengan Keluhan Musculoskeletal Disorders (MSDs) pada Pekerja Beton Sektor Informal di Kelurahan Samata Kecamatan Somba Opu Kabupaten Gowa Tahun 2017. UIN Alauddin Makasar.

Rende, H., Kaunang W,P, J. dan K. (2015). Hubungan Antara Lama Kerja Dan Posisi Kerja Duduk Dengan Keluhan Musculoskeletal Pada Supir Bus Jurusan Manado-Bitung Di Terminal Paal Dua Manado Tahun 2015. In Jurnal Kesmas. Universitas Samratulangi. Universitas Sam Ratulangi.

Safitri, A. (2017). Faktor-Faktor yang Berhubungan dengan Kejadian Musculoskeletal Disorders (MSDs) di Bagian Finishing Unit Coating PT. Pura Barutama Kudus. Jurnal Keperawatan Dan Kesehatan Masyarakat STIKES Cendekia Utama Kudus, 2(5), 11-18.

Siregar, P. A. (2020). Work Posture And Musculoskeletal Disorders Of Coconut Peeler Workers In Sei Apung Village, Asahan Regency. Jurnal Riset Kesehatan, 9(2), 154-158.

Tarwaka. (2015). Ergonomi Industri Dasar-dasar Pengetahuan Ergonomi dan Aplikasi di Tempat Kerja (Pertama). Harapan Press Solo.

Tjahayuningtyas, A. (2019). Faktor Yang Mempengaruhi Keluhan Musculoskeletal Disorders ( MSDs )Pada Pekerja Informal. The Indonesian Journal of Occupational Safety and Health, 8(1), 1-10. https://doi.org/https://doi.org/10.20473/ijosh.v8i1.2019.1.

Wongkar, A. H., M. (2017). Hubungan Postur Kerja Dengan Keluhan Musculoskeletal Pada Kusir Bendi Di Kota Tomohon. Ikmas, 2(7), 1-10. 